Reviews

the percursor of modern authoritarianist thinking in China. Legalism is an interesting philosophical stream in the Chinese tradition, but it never gained a wide acceptance either from the elites or the masses. Early forms of Legalism are attributed to the ancient Chinese philosphers, namely Shang Yang, Shen Pu-hai and Shen Tao (all 4th Century BC), Han Fei Tzu and Li Xu (3rd Century BC).

[4] China's coastal regions, most urbanized and densely populated, have absorbed the largest share in direct foreign investment and Chinese government's attention in infrastructures, facilities and services. This has aggravated the already existing regional imbalance amongst the coastal, interior and remote areas. The 13 top-ranking provinces in terms of international investment, economic output and per capita income, are all along China's eastern and southern coastline (cf. SSB/PRC, 1999; Starr, 1998).China's total coastline is almost 32,000 km, of which $18,000 \mathrm{~km}$ is made up by the mainland shore. China claims sovereignty over some 5,400 islands off its coast $(3,870,000 \mathrm{sq} . \mathrm{km}$. of surface and $14,000 \mathrm{~km}$ of island shore). Socially and economically, these islands can be viewed as part of China's coastal region.

\title{
Deep Environmental Politics: The Role of Radical Environmentalism in Crafting Environmental Policy, by Phillip F. Cramer, Westport, CT: Praeger Books (1998). xvi, 238 pp.
}

\section{Reviewed by Gregory V. Button, School of Public Health, University of Michigan.}

Editor's note: Professor Button is a former journalist and Congressional Fellow who teaches courses on environmental policy and media coverage of environmental issues at the University of Michigan at Ann Arbor.

As the author notes in his preface, few books have been published to date that measure the influence of the Deep Ecology philosophy on the environmental movement, especially its influence on environmental policy. Unfortunately, by the time one has finished reading this book the temptation may be to conclude that the reason for this deficiency is the lack of influence deep ecology has had on the formulation of policy.

The book is divided into three parts. Part One provides the reader with an introduction to the Deep Ecology perspective. Cramer's overview is adequate, if uninspiring. He sketches for the uninformed reader the basic tenets of the philosophical tradition that inspired the Deep Ecology movement and provides a cursory overview of the fundamental canons of the movement. Thus, he sketches for the reader Deep Ecology's rejection of an anthropocentric environmentalism and its major paradigm shift to an environmentalism that is predicated on "ecocentrism" that attempts to create major changes in our perceptions, values and lifestyles. Stressing a harmony with nature and the intrinsic worth of all species, Cramer describes a philosophy that rejects the excessive 


\section{Reviews}

human interference with the natural world and writes of the need for extensive societal changes that shun centralization and promote local autonomy. However, as with the rest of the book, the author's writing reads more like a tepid outline than a mature textual narration of the material.

The remainder of the book adheres to this tedious style. In Part Two, in which Cramer attempts to analyze Deep Ecology and its impact on contemporary politics, he examines environmental legislation, Congressional testimony and court decisions in his quest to investigate the influence of the movement. His approach to these subjects lacks the analytical rigor to which most social scientists are accustomed. His minimalist approach results in simply summarizing the evidence in such a way that he devotes superficial attention to such major and complex documents as the 1963 Clean Air Act.

Thus congressional legislation is tersely examined for a speck of influence or mere mention of deep ecology or any discourse that might be even remotely related to the movement. The reader is provided with no overview of the legislation or its purpose. The result is a run of seemingly unrelated paragraphs that tick through recent legislative acts one after another with no analytical connection or textual passage from one to another.

As a result, the book does not cohere, either within its respective parts, or in its overall aim of assessing the influence of Deep Ecology on American environmental policy. Setting aside its superficial analytical framework, the book lacks any connective tissue that allows the reader to make sense of the seemingly unrelated comments within any single chapter, let alone to make any sense of the book as a whole. This litany of near-miss analysis continues throughout Part Two as Cramer turns his eye first to Congressional testimony and then to the legal system.

At the conclusion of his survey of fifty-two legal articles, he states. "it would not be prudent to reach a make sweeping conclusions based on the small number of articles in this study" (p. 172). The same may well be said for his superficial analysis of all the texts that he employs in the book. When the author does make conclusions, they have a hollow ring to them such as the following: "The study found that the language of Deep Ecology is rarely used in Congressional hearings" (p. 221). As unsurprising as this is, Creamer is at a loss to make any analysis of why it is the case, or what effect, if any, is felt on Congressional policy. For that matter, Cramer is equally inattentive to the ways in which Congressional policy is distinguished because the influence of Deep Ecology appears to be altogether missing.

Part Three, "The Media Coverage of Deep Ecology," maintains the same plodding approach as the author attempts to study 372 articles about deep ecology (how and why they were chosen, or why they are taken to be representative of the media is not clear). This review "substantiates" that the media coverage of Deep Ecology is "negative." Cramer never makes clear whose whose claim is it that he "substantiates?" And as with much of the book's material, we are never quite sure who is the referent, let alone who composes the Deep Ecology movement.

Setting aside the substance of the conclusions, the reader is forced to ask what this means, because the meanings and their implications for influence on policy, are left wholly unexamined and only at best inferred. Once again, in this altogether too brief chapter that purports to examine a sizable body of media texts, the author devotes sparse attention to media categories and thus, for example, a mere ten sentences suffices for a discussion of scientific magazines. Moreover, of the hundreds of articles Cramer examines, he never clearly delineates how many were scientific magazines, how many were U.S. newspapers, and how many from other media outlets. Furthermore, in his analysis he seems to conflate not only sources, but categories; thus he conflates book reviews along with newspaper articles, making an unwieldy mess of media evidence.

In his final media analysis chapter he employs what he terms an "admittedly subjective" method, which provides a statistical analysis of 372 articles spanning 15 years. While this time he does provide us with a breakdown of the media sources, he is merely concerned with whether the articles mention Deep Ecology in a negative or positive manner. What the ultimate meaning of his findings are for his investigation is left implicit and unclear. What after all, is the significance of some media coverage being positive, negative, mixed or unscoreable? What relevance any of this has with the stated objectives of the book is left poorly underdeveloped. 
Reviews

In the book's conclusion, which provides us with as little insight as the text, Cramer rather surprisingly states that "the book has attempted to illustrate how deep ecology and radical environmentalism have tried to reverse the engines of society and thus craft a new environmental policy." This statement seems wholly out of keeping with much of what the book is about. It seems rather that the book has tried to measure how successful (as the intended objective stated at the outset) Deep Ecology has been instead of illustrating "how" it has tried to influence contemporary environmental policy. This lack of clarity of purpose serves only to underscore the confusion and futility of the disparate and superficial evidence that the author has assembled to conduct his study.

\section{The Evolution of Inequality: War, State Survival, and Democracy in Comparative Perspective, by Manus I. Midlarsky (1999), Stanford, CA: Stanford University Press, xiv, 349 pp.}

\section{Reviewed by Patricia Kachuk, Lecturer, Department of Anthropology and Sociology, University of British Columbia.}

Midlarsky undertakes the daunting task of explaining, mathematically and empirically, the process of the evolution of inequality and its role in state formation and state dissolution. It is argued that inequality, far from being a product of a particular economic structure, as Marxists claim, was instead preceded by a scarcity of valued resources and evolved primarily from a "random process of allocation, subdivision or expansion," and secondarily from the genetic capability of some who were better equipped to endure under these conditions of scarcity. Midlarsky's theory of the origin of the state proclaims that inequality - the motor of state formation - preceded warfare, rather than the reverse, which is the common belief. Thus he argues that while warfare is sufficient to bring about state formation, it is not a necessary condition meaning that democracy and other such peaceful mechanisms are more reliable predictors of state formation and its continuation. Midlarsky argues that unlike warfare, expansion is both necessary and sufficient for the origins of the state. Neither, Midlarsky maintains, is warfare a necessary condition of state dissolution. Rather, he posits that if democracy is in place prior to a major conflict the state will prevail, if not, the state will dissolve.

In Part I, Midlarsky develops his theoretical-probabilistic argument, wherein he links scarcity to inequality. Using both exponential and geometric distributions, Midlarsky tries to demonstrate mathematically that under conditions of scarcity, there will be an exponentially declining probability of attaining valued resources. The greater the scarcity of these resources the more rapid the exponential decline, resulting in a far larger portion of a population being unable to obtain these valued resources. Thus, Midlarsky argues that if there is scarcity of desired resources then inequality exists, and given his assumption of equality of opportunity, who gets these valued resources and who does not is a random process. Midlarsky uses the example of agricultural land to illustrate his theory of exponential subdivision under conditions of scarcity. Agricultural land is a finite resource and beyond a certain point no more can be generated. Therefore, in situations where societies have high population densities, over time all arable land will be developed, and given that there is no land for expansion (as in island and other geographically constrained societies), and that primogeniture is absent (meaning land will be equally distributed among male 